\title{
Biotechnological and chemical analysis of Egyptian Diospyros kaki L. cv. Costata grown in Egypt
}

\author{
Seham Salah El-din El-Hawary', Soad Hanna Tadros ${ }^{1}$, Hussein Taha², Mona Abdelmohsen², \\ Naglaa Mohamed Nazif ${ }^{3}$, Iman El Sheikh ${ }^{3^{*}}$ and Medhat Seif El-Nasr ${ }^{3}$
}

\begin{abstract}
Background: Diospyros kaki L. is considered one of the most important economical medicinal plant in Chinese herbal medicine belonging to family Ebenaceae as it contains varied secondary metabolites and used in treatment of many diseases. For there is an efficient and promising protocol for in vitro propagation of Diospyros kaki L. CV. Costata was established Diospyros kaki L. cv. Costata although it is difficult to initiate it in sterilized artificial media due to the browning of tissue caused by oxidation of phenolics. An efficient sterilizing method for leaf and internode explants was obtained by using $0.2 \%$ mercuric chloride $\left(\mathrm{Hg}_{2} \mathrm{Cl}_{2}\right)$ for $5 \mathrm{~min}$. Woody plant medium (WPM) supplemented with $2 \mathrm{mg} / \mathrm{l}$ zeatin $(\mathrm{Zt})+5 \mathrm{mg} / \mathrm{l}$ isopentenyl adenine ( $2 \mathrm{iP})$. Calli were induced on Murashige and Skoog medium (MS) augmented with $10 \mathrm{mg} / \mathrm{lt}+10 \mathrm{mg} / \mathrm{l}$ indole-3-acetic acid (IAA) + $500 \mathrm{mg} / \mathrm{l}$ polyvinylpyrolidone (PVP) $+0.1 \mathrm{mg} / \mathrm{l}$ thiamine $\mathrm{HCL}$ from internode explants. However, the regeneration efficiency was obtained with $1 / 2$ MS-media fortified with $1 \mathrm{mg} / \mathrm{l} \mathrm{Zt}+2 \mathrm{mg} / \mathrm{l} \mathrm{IAA}+4 \mathrm{mg} / \mathrm{l}$ benzylaminopurine (BAp) $+0.5 \mathrm{~g} / \mathrm{l}$ PVP from internode calli explants.
\end{abstract}

Results: The highest amounts of scopoletin 57.08, 26.42, and 25.30 ( $\mu \mathrm{g} / \mathrm{g}$ DW) were detected using reversed phase of high-performance liquid chromatography (RP-HPLC) in leaves extract of intact plant followed by regenerated and calli cultures of internod explants, respectively.

Conclusion: This study is the first record for in vitro propagation and production of secondary metabolites from Diospyros kaki L. using biotechnology techniques. Chemical anaysis were carried out using HPLC technique.

Keywords: Diospyros kaki L. cv. Costata, Explants, Mercuric chloride, Zeatin, HPLC

\section{Background}

Plants that possess therapeutic properties or exert beneficial pharmacological effects on the human body are generally designated as medicinal plants. They naturally synthesize and accumulate some secondary metabolites, like alkaloids, sterols, terpenes, flavonoids, saponins, cyanogenic glycosides, tannins, resins, lactones, quinines, and volatile oils (Ramachandra \& Ravishankar, 2002). Medicinal plants have been used for the treatment of diseases, since the dawn of

\footnotetext{
*Correspondence: emanseody@gmail.com

${ }^{3}$ Phytochemistry Department, National Research Centre, 33 El Bohouth St.

(Former El Tahrir St.), Dokki, P. O. 12622, Giza, Egypt

Full list of author information is available at the end of the article
}

the time (Motaleb et al., 2011). Family Ebenaceae include four genera Diospyros, Euclea, Lissocarpa, and Royena. It consists of woody shrubs and trees distributed in the tropical, sub-tropical, and temperate areas and are known worldwide for its biological activities. The largest, important, and economically genus of Ebenaceae is Diospyros with approximately 300 species which occurs in Asia and Pacific area (De Vera \& Santiago, 2014; Matsushita et al., 2010). Diospyros kaki L. cv. Costata is well known in Chinese herbal medicine and used for prevention and treatment of hypertension, cancer, diabetes, and atherosclerosis. Moreover, it contains tannins, phenols, and flavonoids which are the most active constituents of this plant (Tang \& Eisenbrand, 1992).

\section{Springer Open}

() The Author(s). 2020 Open Access This article is licensed under a Creative Commons Attribution 4.0 International License, which permits use, sharing, adaptation, distribution and reproduction in any medium or format, as long as you give appropriate credit to the original author(s) and the source, provide a link to the Creative Commons licence, and indicate if changes were made. The images or other third party material in this article are included in the article's Creative Commons licence, unless indicated otherwise in a credit line to the material. If material is not included in the article's Creative Commons licence and your intended use is not permitted by statutory regulation or exceeds the permitted use, you will need to obtain permission directly from the copyright holder. To view a copy of this licence, visit http://creativecommons.org/licenses/by/4.0/. 
Diospyros kaki L. cv. Costata is the main persimmon variety progressively consumed in the Egyptian market and exportation (Fathi et al., 2011). Further, the in vitro culture and propagation of this plant is more important; however, it is very difficult to be initiated in sterilized artificial media due to the browning of tissue, which is caused by oxidation of polyphenols (Monaco et al., 1977) , and it may be the first record on in vitro calli production and regeneration induction from Diospyros kaki L. cv. Costata growing in Egypt.

This study aimed to obtain calli and regeneration from leaf and internode explants of Diospyros kaki L. cv. Costata. Further, carrying out of chemical analysis using RPHPLC technique, to figure out the secondary metabolites accumulated in calli and regenerated shootlets compared to leaves of Diospyros kaki L. cv. Costata intact plant.

\section{Material and methods}

\section{Plant material}

Diospyros kaki L. cv. Costata explants (leaves and internods) were obtained from Aga Center, Fisha Village, Dakahlia Governorate, Egypt. It was kindly authenticated by Dr. Abd El-Halim Abd El-Mogali Mohamed, senior researcher in Flora and Phytotaxonomy Researches Department, Agricultural Museum, Dokki, Giza, Egypt.

\section{Chemical materials}

Benzyl aminopurine (BAp) (Santa Cruz Biotechnology, USA ), indole-3-acetic acid (IAA) (Science Lab. USA), Mc Cown's woody plant medium with vitamins (WPM) (Melford Laboratories Ltd.), Mercuric chloride $\left(\mathrm{Hg}_{2} \mathrm{Cl}_{2}\right)$ (Mallinckrodt. Inc. Paris), Murashige, and Skoog with vitamins (MS) (Caisson Laboratories, USA ), Polyvinyl pyrrolidone (PVP) (Alfa Aesar, USA), 6- $(\gamma, \gamma$-dimethyl allylamino purine (2iP), naphthaleneacetic acid (NAA), kinetin (KN), (Santa Cruz Biotechnology, USA), and zeatin (ZT) (Science Lab., USA).

\section{Sterilization of explants}

Internodes (stem cuttings) $1-1.5 \mathrm{~cm}$ length and leaf explants 3-5 mm were excised from a shrub tree of Diospyros kaki L. cv. Costata. Further, these explants were washed with tap water for $1 \mathrm{hr}$. using detergent solution. Then, they were surface sterilized by immersion in $70 \%$ ethanol for $5 \mathrm{~s}$ followed by four washes using sterile distilled water. Subsequently, they were immersed in solution of $\mathrm{Hg}_{2} \mathrm{Cl}_{2}$ at two concentrations $(0.1$ or $0.2 \%)$ for 5 min to study their effects on sterilization process. Explants were cultured under aseptic condition on half MS nutrient medium.

\section{Development media}

The disinfected internodes and leaves explants were cultured on different solidified and modified nutrient media. These types of nutrient media were designed to study its effects on development characters (calli induction or primordial shootlets regeneration). All used media were augmented with $30(\mathrm{w} / \mathrm{v})$ sucrose and agar $0.7 \%$. The $\mathrm{pH}$ of all used media was adjusted to 5.8 with $0.1 \mathrm{~N}$ each of $\mathrm{KOH}$ (potassium hydroxide) or $\mathrm{HCl}$ (hydrocholric acid). The different type of nutrient media were distributed into $300 \mathrm{ml}$ glass jars where each jar contained $50 \mathrm{ml}$ and sterilized by autoclaving for $23 \mathrm{~min}$ at $121{ }^{\circ} \mathrm{C}$. The cultures media were incubated in complete darkness for one week. Then, they were exposed to illumination light (2000 lux) with fluorescent lamp and kept at $26 \pm 1{ }^{\circ} \mathrm{C} 16 \mathrm{~h}$ photoperiod for 4 weeks. The composition of modified nutrient media was structured as follows:

\begin{tabular}{ll}
\hline 1 & $1 / 2 \mathrm{MS}$-free growth regulators \\
2 & $\mathrm{WPM}+2 \mathrm{mg} / \mathrm{Zt}+5 \mathrm{mg} / \mathrm{l} 2 \mathrm{PP}$ \\
3 & $\mathrm{MS}+2 \mathrm{mg} / \mathrm{l} \mathrm{BAp}+0.2 \mathrm{mg} / \mathrm{I} \mathrm{NAA}$ \\
4 & $\mathrm{MS}+5 \mathrm{mg} / \mathrm{l} \mathrm{BAp}+1.1 \mathrm{mg} / \mathrm{KN}$ \\
\hline
\end{tabular}

Each treatment consisted of 10 replicates (jars) and each replicate contained one explant (leaf or internode)

\section{Calli induction}

Sterilized internode explants were excised from previously in vitro grown shootlets on WPM supplemented with 2 $\mathrm{mg} / \mathrm{l} \mathrm{ZT}+5 \mathrm{mg} / \mathrm{l} 2 \mathrm{iP}$. Further, cut and cultured on MSmedium (30 w/v sucrose and $7 \mathrm{~g}$ agar) or WPM supplemented with different combinations of growth regulators as follows:

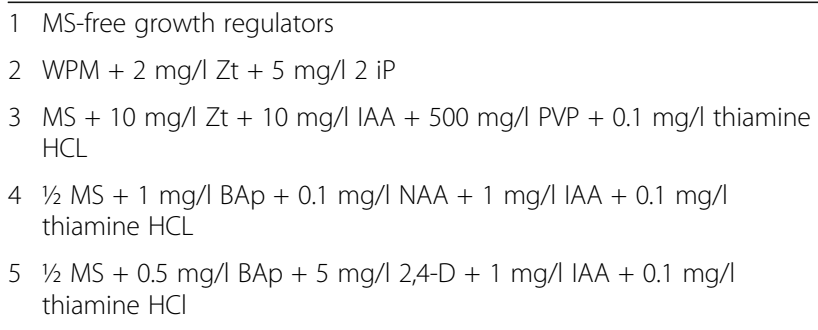

\section{Regeneration induction}

In this experiment, obtained calli from MS supplemented with $10 \mathrm{mg} / \mathrm{l} \mathrm{Zt}+10 \mathrm{mg} / \mathrm{l} \mathrm{IAA}+500 \mathrm{mg} / \mathrm{l} \mathrm{PVP}+0.1 \mathrm{mg} / \mathrm{l}$ thiamine HCL were subjected to the following nutrient media to induce shootlets regeneration as follows:

\footnotetext{
$1 \frac{1}{2} \mathrm{MS}+0.22 \mathrm{mg} / \mathrm{l}$ thidiazuron (TDZ) $+1 \mathrm{mg} / \mathrm{l} \mathrm{IAA}+500 \mathrm{mg} / \mathrm{l} \mathrm{PVP}+$ $40 \mathrm{mg} / \mathrm{l}$ adenine sulfate $+0.1 \mathrm{mg} / \mathrm{l}$ thiamine $\mathrm{HCL}$

2 1/2 MS + $1 \mathrm{mg} / \mathrm{l} \mathrm{Zt}+2 \mathrm{mg} / \mathrm{lAA}+4 \mathrm{mg} / \mathrm{l}$ BAp $+0.5 \mathrm{~g} / \mathrm{l} \mathrm{PVP}$
}

Where all cultures were incubated under darkness for 3 days then, incubated under light condition $16 / 18 \mathrm{~h}$ (2000 lux) for 4 weeks at $26 \pm 1{ }^{\circ} \mathrm{C}$

\section{Chemical analysis}

The present study was performed for the qualitative and quantitative determination of flavonoid and other phenolic contents in leaves-derived extracts of intact 
Table 1 Effect of different type of nutrient media on development ${ }^{a}$ percentage of leaf and internode explants of Diospyros kaki L. cv. Costata

\begin{tabular}{|c|c|c|c|c|c|}
\hline \multirow[t]{3}{*}{ No. } & \multirow[t]{3}{*}{ Type of nutrient media ${ }^{b}$} & \multicolumn{4}{|c|}{ Explants development percentage } \\
\hline & & \multicolumn{2}{|l|}{ Leaf } & \multicolumn{2}{|l|}{ Internode } \\
\hline & & Light & Dark & Light & Dark \\
\hline 1 & $1 / 2$ MS-free growth regulators & - & - & - & - \\
\hline 2 & 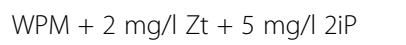 & - & - & $50 \pm 5.65$ & $50 \pm 4.25$ \\
\hline 3 & $\mathrm{MS}+2 \mathrm{mg} / \mathrm{l} \mathrm{BAp}+0.2 \mathrm{mg} / \mathrm{I} \mathrm{NAA}$ & - & - & $20 \pm 3.15$ & $20 \pm 2.25$ \\
\hline 4 & $\mathrm{MS}+5 \mathrm{mg} / \mathrm{l} \mathrm{BAp}+1.1 \mathrm{mg} / \mathrm{l} \mathrm{KN}$ & - & - & - & - \\
\hline
\end{tabular}

${ }^{a}$ Explants were developed to either calli or shootlets regeneration

${ }^{b}$ Each treatment was the mean of 10 replicates \pm SE

plant; calli and regenerated shootlets of Diospyros kaki L. cv. Costata. Samples were prepared as $1 \mathrm{~g}$ of dried powdered material, further, extracted with aqueous methanol (80\%); filtered and evaporated. Before quantization by HPLC, the samples were filtered through a $0.4 \mu \mathrm{m}$ membrane filter into vial for injection.

\section{Specification of RP-HPLC instrument}

Hewlett-Packard (series 1050) equipped with autosampling injector, solvent degasser, ultraviolet (UV) detector set at $280 \mathrm{~nm}$ and $330 \mathrm{~nm}$ for phenolics determination, quaternary HP pump (series 1050), and a lichrosorb $\mathrm{RP} \mathrm{C}_{18}$ column $(4.0 \mathrm{~mm}$ i.d. $\times 250 \mathrm{~mm}$; particle size $5 \mu \mathrm{m}$ ) (Merck, Darmstadt) was used. The column temperature was maintained at room temperature. Isocratic separation was carried out using methanol and acetonitrile $(2: 1)$ as a mobile phase at flow rate of $1 \mathrm{ml} / \mathrm{min}$. Authentic phenolics were dissolved in mobile phase and injected into RPHPLC. The retention time and peak area were used to calculate phenolics concentrations by the data analysis of Hewlett-Packard software (Goupy et al., 1999; Mattila et al., 2000).

\section{Statistical analysis}

The design of all experiments was completely randomized and the obtained data were statistically analyzed using standard error $( \pm \mathrm{SE})$ according to the method described by Snedecor and Cochran (Snedecor \& Cohchran, 1967).

\section{Results}

\section{Sterilization experiment}

Regarding this experiment, leaf explants were treated with $0.1 \%$ of $\mathrm{Hg}_{2} \mathrm{Cl}_{2}$ for $5 \mathrm{~min}$ resulted in $37 \%$ contamination and 63\% survival explants. However, treated leaf explants with $0.2 \%$ of $\mathrm{Hg}_{2} \mathrm{Cl}_{2}$ for $5 \mathrm{~min}$ resulted in $45 \%$ contamination and $55 \%$ survival explants, respectively. On the other hand, treated internode explants with $0.1 \%$ of $\mathrm{Hg}_{2} \mathrm{Cl}_{2}$ for $5 \mathrm{~min}$ recorded $65 \%$ and $35 \%$ of contaminated and survival explants, respectively. However, treated internode explants with $0.2 \%$ of $\mathrm{Hg}_{2} \mathrm{Cl}_{2}$ for 5 min recorded the lowest percentage of contamination (20\%) in correlation with the highest percentage of survival explants (80\%).

Therefore, it can be concluded that, treated internode explants of Diospyros kaki L. cv. Costata with $0.2 \%$ of

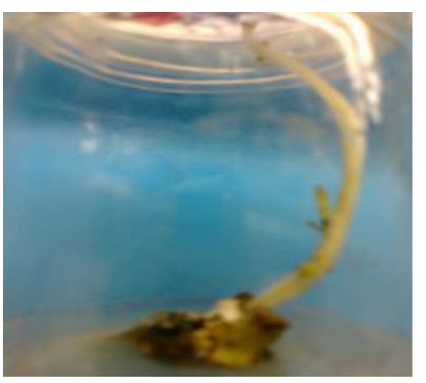

A -After 4 weeks (Dark)

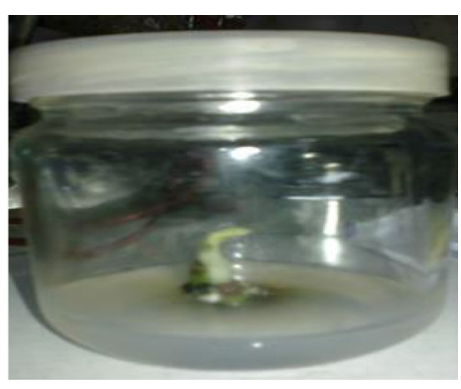

B -After 4 weeks (Light)

Fig. 1 a, $\mathbf{b}$ Effect of supplementation of WPM with $2 \mathrm{mg} / \mathrm{l}$ Zt and $5 \mathrm{mg} / \mathrm{l}$ 2iP on development stage (calli initiation or shootlet regeneration) from internode explant of Diospyros kaki L. cv. Costata 
Table 2 Effect of different type of nutrient media on percentage of calli induction calli fresh, and dry weights ( $\mathrm{g} / \mathrm{jar}$ ) induced from internode explants of Diospyros kaki L. cv. Costata ${ }^{a}$

\begin{tabular}{|c|c|c|c|c|}
\hline No. & Mediab $^{b}$ & $\%$ of callus induction & $\begin{array}{l}\text { Calli fresh weight } \\
\text { (g/jar) }\end{array}$ & $\begin{array}{l}\text { Calli dry weight } \\
\text { (g/jar) }\end{array}$ \\
\hline 1 & MS-free growth regulators & $\longrightarrow$ & - & $\longrightarrow$ \\
\hline 2 & $W P M+2 m g / l ~ Z t+5 m g / l ~ 2 i P$ & $30 \pm 4.15$ & $0.68 \pm 0.32$ & $0.11 \pm 0.06$ \\
\hline 3 & $\mathrm{MS}+10 \mathrm{mg} / \mathrm{l} \mathrm{Zt}+10 \mathrm{mg} / \mathrm{I} \mathrm{IAA}+500 \mathrm{mg} / \mathrm{l} \mathrm{PVP}+0.1 \mathrm{mg} / \mathrm{l}$ thiamine $\mathrm{HCL}$ & $60 \pm 5.25$ & $6.69 \pm 0.79$ & $0.38 \pm 0.11$ \\
\hline 4 & $1 / 2 \mathrm{MS}+1 \mathrm{mg} / \mathrm{l} \mathrm{BAp}+0.1 \mathrm{mg} / \mathrm{l} \mathrm{NAA}+1 \mathrm{mg} / \mathrm{I} \mathrm{AA}+0.1 \mathrm{mg} / \mathrm{l}$ thiamine $\mathrm{HCL}$ & $10 \pm 2.33$ & - & - \\
\hline 5 & $1 / 2 \mathrm{MS}+0.5 \mathrm{mg} / \mathrm{l} \mathrm{BAp}+5 \mathrm{mg} / \mathrm{l} 2,4-\mathrm{D}+1 \mathrm{mg} / \mathrm{I} \mathrm{IAA}+0.1 \mathrm{mg} / \mathrm{l}$ thiamine $\mathrm{HCl}$ & $40 \pm 4.25$ & $3.40 \pm 0.75$ & $0.13 \pm 0.05$ \\
\hline
\end{tabular}

${ }^{\mathrm{a}}$ Cultures were incubated under dark condition for four weeks at $26 \pm 1{ }^{\circ} \mathrm{C}$

${ }^{b}$ Each treatment was the mean of 10 replicates \pm SE

$\mathrm{Hg}_{2} \mathrm{Cl}_{2}$ for 5 min was the best to obtain lowest percentage of contamination in correlation of highest percentage of sterilized survival explants.

\section{Development media}

Data in Table 1 and Fig. 1a, b clearly show that the effect of different type of nutrient media on leaf and internode explants development percentage. The highest percentage of explants development (50\%) was recorded with internode explants cultured on WPM supplemented with $2 \mathrm{mg} / \mathrm{l} \mathrm{Zt}+5 \mathrm{mg} / \mathrm{l} 2 \mathrm{iP}$ and incubated under either dark or light conditions. Whereas, leaf explants were completely failed on development using different nutrient media. This result may be attributed to the high accumulation and release of phenolic compounds from leaf explants to the culture media upon blacking which make toxicity. Further, the internode explants will be subjected to calli and regeneration experiments.

\section{Callus induction experiment}

Data tabulated in Table 2 show that the highest percentage of calli induction (60\%) was recorded with supplementation of full MS medium with $10 \mathrm{mg} / \mathrm{l} \mathrm{Zt}$ $+10 \mathrm{mg} / \mathrm{l} \mathrm{IAA}+500 \mathrm{mg} / \mathrm{l} \mathrm{PVP}+0.1 \mathrm{mg} / \mathrm{l}$ thiamine HCL. While the lowest percentage of calli induction (10\%) was recorded with augmentation of $1 / 2 \mathrm{MS}$ medium with $1 \mathrm{mg} / \mathrm{l} \mathrm{BAp}+0.1 \mathrm{mg} / \mathrm{l} \mathrm{NAA}+1 \mathrm{mg} / \mathrm{l}$ IAA $+0.1 \mathrm{mg} / \mathrm{l}$ thiamine HCL. However, culturing of internode explants on MS medium-free growth regulators failed completely on callus induction (Fig. 2).

On the other hand, and regarding calli fresh and dry weights, the maximum calli fresh and dry weights (6.69, $0.38 \mathrm{~g} / \mathrm{jar}$ ) were recorded with culturing of internode explants on MS medium supplemented with $10 \mathrm{mg} / \mathrm{l} \mathrm{Zt}$ $+10 \mathrm{mg} / \mathrm{l} \mathrm{IAA}+500 \mathrm{mg} / \mathrm{l} \mathrm{PVP}+0.1 \mathrm{mg} / \mathrm{l}$ thiamine $\mathrm{HCL}$, respectively. While the minimum calli fresh and dry weights $(0.68,0.11 \mathrm{~g} / \mathrm{jar})$ were recorded with supplementation of WPM with $2 \mathrm{mg} / \mathrm{l} \mathrm{Zt}+5 \mathrm{mg} / \mathrm{l} 2 \mathrm{iP}$, respectively. However, no positive results were observed with culturing of internode explants on MS mediumfree growth regulators.

\section{Regeneration induction experiment}

Data tabulated in Table 3 and Fig. 3 clearly show that the highest percentage of regenerated shootlets (50\%) was recorded with supplementation of half MS medium with $1 \mathrm{mg} / \mathrm{l} \mathrm{Zt}+2 \mathrm{mg} / \mathrm{l} \mathrm{IAA}+4 \mathrm{mg} / \mathrm{l} \mathrm{BAp}+0.5$ g/l PVP. While the lowest percentage of regenerated shootlets (10\%) was recorded with fortified of half MS medium with $0.22 \mathrm{mg} / \mathrm{l} \mathrm{TDZ}+1 \mathrm{mg} / \mathrm{l} \mathrm{IAA}+500 \mathrm{mg} / \mathrm{l}$ $\mathrm{PVP}+40 \mathrm{mg} / \mathrm{l}$ Adenine sulfate $+0.1 \mathrm{mg} / \mathrm{l}$ thiamine HCL.

Regarding the number of regenerated shootlets, numbers of leaves/shoot, and length of shoot $(\mathrm{cm})$, the maximum number of shoots/explant (3.4), number of leaves/shoot (3.8), and longest shoot $(5 \mathrm{~cm})$ were recorded with fortified of $1 / 2 \mathrm{MS}$ with $1 \mathrm{mg} / \mathrm{l} \mathrm{Zt}+2 \mathrm{mg} / \mathrm{l}$ $\mathrm{IAA}+4 \mathrm{mg} / \mathrm{l} \mathrm{BA}+0.5 \mathrm{~g} / \mathrm{l} \mathrm{PVP}$ compared with other used medium.

\section{Chemical analysis}

The chemical analysis of phenolic compounds in leaves of intact plant; calli of internode explants and regenerated shootletes extracts of Diospyros kaki L. cv. Costata were carried out using RP-HPLC. Phenolic compounds appeared at $\lambda_{\max } 280 \mathrm{~nm}$ using HPLC analysis are shown in Table 4.

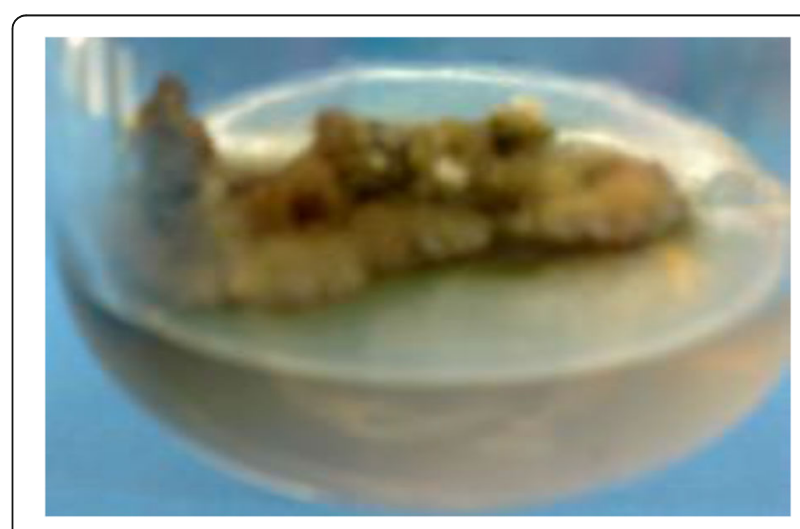

Fig. 2 Callus induction from internode explant cultured on MS-medium supplementation with $10 \mathrm{mg} / \mathrm{l} \mathrm{Zt}+10 \mathrm{mg} / \mathrm{IAA}+500 \mathrm{mg} / \mathrm{l} \mathrm{PVP}+0.1$ $\mathrm{mg} / \mathrm{l}$ thiamine $\mathrm{HCL}$ (cultures were incubated under dark condition for 4 weeks at $26 \pm 1^{\circ} \mathrm{C}$ ) 
Table 3 Effect of supplementation of half MS nutrient medium with two concentrations of growth regulators on percentage, number of regenerated shoots/explant, number of leaves/shoot, and length of shoot $(\mathrm{cm})$ induced from internode calli explants of Diospyros kaki L. cv. Costata ${ }^{a}$

\begin{tabular}{|c|c|c|c|c|c|}
\hline & 1/2 MS medium supplemented with ${ }^{b}$ & $\begin{array}{l}\% \text { of regenerated } \\
\text { shootlets }\end{array}$ & $\begin{array}{l}\text { Number of } \\
\text { regenerated } \\
\text { shoots/explant }\end{array}$ & $\begin{array}{l}\text { Number of } \\
\text { leaves/ } \\
\text { shoot }\end{array}$ & $\begin{array}{l}\text { Length of } \\
\text { shoot }(\mathrm{cm})\end{array}$ \\
\hline 1 & $0.22 \mathrm{mg} / \mathrm{I} \mathrm{TDZ}+1 \mathrm{mg} / \mathrm{IAA}+500 \mathrm{mg} / \mathrm{l} \mathrm{PVP}+40 \mathrm{~g} / \mathrm{l}$ adenine sulfate $+0.1 \mathrm{mg} / \mathrm{l}$ thiamine $\mathrm{HCL}$ & $10 \pm 2.15$ & $1.3 \pm 0.3$ & $2.3 \pm 0.3$ & 1.2 \\
\hline 2 & $1 \mathrm{mg} / \mathrm{l} \mathrm{Zt}+2 \mathrm{mg} / \mathrm{I} \mathrm{IAA}+4 \mathrm{mg} / \mathrm{l} \mathrm{BAp}+0.5 \mathrm{~g} / \mathrm{l} \mathrm{PVP}$ & $50 \pm 5.25$ & $3.4 \pm 0.5$ & $3.8 \pm 0.3$ & 5 \\
\hline
\end{tabular}

${ }^{a}$ Cultures were incubated under light condition for four weeks at $26 \pm 1{ }^{\circ} \mathrm{C}$

${ }^{\mathrm{b}}$ Each treatment was the mean of 10 replicates $\pm \mathrm{SE}$

From the result above, scopoletin was found to be the highest compound recorded $(\mu \mathrm{g} / \mathrm{g} \mathrm{DW})$ in leaves of intact plants, calli, and regenerated shootlets extracts 57.08, 25.30, and 26.42, respectively. However, pyrogallol $(8.8 \mu \mathrm{g} / \mathrm{g} \mathrm{DW})$ was the lowest amount recorded in leaves extract while resveratrol and coumarin were recorded as the lowest amount in calli extracts $(0.5 \mu \mathrm{g} / \mathrm{g}$ DW $)$ and ellagic $(1.03 \mu \mathrm{g} / \mathrm{g}$ DW) in regenerated shootlets.

As well as the chemical analysis of phenolic compounds in leaves of intact plant; calli of internode explants and regenerated shootletes extracts of Diospyros kaki L. cv. Costata were carried out using RP-HPLC. Phenolic compounds were appeared at $\lambda_{\max } 330 \mathrm{~nm}$ as shown in Table 5 .

From the previous data, it can be concluded that kaempferol was the major compound in leaves extract $(80.9 \mu \mathrm{g} / \mathrm{g} \mathrm{DW})$, while luteo.6-arbinose 8-glucose recorded the highest amount in calli extract and regenerated shootlets (65.1, $70.4 \mu \mathrm{g} / \mathrm{g} \mathrm{DW})$, respectively. Luteolin was detected only in leaves extract $(62.59 \mu \mathrm{g} / \mathrm{g}$ DW). However, quercetin-3-O-glucoside $(1.5 \mu \mathrm{g} / \mathrm{g} \mathrm{DW})$

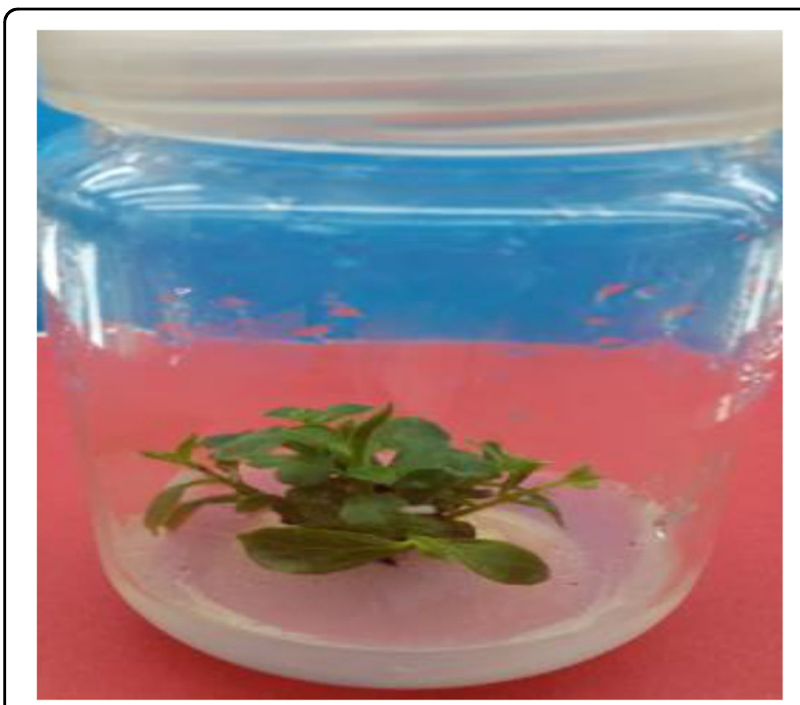

Fig. 3 Shootlets regenerated from internode calli explants of Diospyros kaki L. cv. Costata cultured on 1/2 MS-media supplemented with $1 \mathrm{mg} / \mathrm{l}$ $\mathrm{Zt}+2 \mathrm{mg} / \mathrm{l} \mathrm{IAA}+4 \mathrm{mg} / \mathrm{lBAp}+0.5 \mathrm{~g} / \mathrm{IPVP}$ (cultured was incubated under light condition (2000 lux) at $26 \pm 1{ }^{\circ} \mathrm{C}$ for 8 weeks) was detected only in calli extract; this variation may be due to changes in metabolic pathways.

\section{Discussion}

May be it is the first protocol for in vitro propagation of Diospyros kaki L. cv. Costata. Moreover, there is no reliable method was defined for culturing calli and shootlets regneration from Diospyros kaki L. cv. Costata grown in Egypt.

The production of secondary metabolites in plant calli or cell cultures has been reported from various medicinal plants. Thus, and in agreement with our previous results (Nigra et al., 1987), (Toppei et al., 1987), (Jha et al., 1988), Shirley 2000, Phillipson, 2005, Taha et al., 2009) reported that many phenolic compounds in plants are synthesized by the phenylpropanoid pathway which is typically initiated by phenyl alanine. Further, Monaco et al., 1977) reported that browning of tissue is caused by the oxidation of tannin and polyphenols and the formation of quinones which are highly reactive and toxic to the plant tissues.

Regarding sterilization experiment, the optimum concentration of $\mathrm{Hg}_{2} \mathrm{Cl}_{2}$ was $0.2 \%$ for 5 min recorded the lowest percentage of contamination and the highest survival rate in internode explants of Diospyros kaki L. cv. Costata. The obtained results are in agreement with Wang et al., 2010 who indicated that $0.1 \%$ of $\mathrm{Hg}_{2} \mathrm{Cl}_{2}$ for 15 min was more sufficient to obtain the highest survival rate of the explants in the dormant period of Boaibayuehuang Diospyros kaki.

In addition, the most suitable media for explants development was WPM medium supplemented with $30 \mathrm{~g} / \mathrm{l}$ sucrose in combination with growth regulators as $2 \mathrm{mg} / \mathrm{l}$ $\mathrm{ZT}+5 \mathrm{mg} / \mathrm{l} 2 \mathrm{iP}$ in dark condition, then transferred to light which gives the highest percentage of shoots development from the used explants. The extracted results were in contrast with Giordani et al., 2013 who used half MS supplemented with $20 \mathrm{~g} / \mathrm{l}$ sucrose $+2.2 \mathrm{mg} / \mathrm{l} \mathrm{ZT}+5 \mathrm{mg} / \mathrm{l}$ BA for in vitro establishment of shoot induction of Diospyros kaki cultivars (Hiratanenashi, jiro, kaki Tip, and Fuyu).

Concerning calli induction experiment, it was found that MS medium supplemented with $10 \mathrm{mg} / \mathrm{l} \mathrm{Zt}+10 \mathrm{mg} /$ 
Table 4 Results of phenolic compounds identified by RP-HPLC in different extracts $(80 \% \mathrm{MeOH})$ of leaves, calli, and regenerated shoots of Diospyros kaki L. Cv. Costata that appear at $\lambda_{\max } 280 \mathrm{~nm}$

\begin{tabular}{|c|c|c|c|c|c|}
\hline \multirow[t]{2}{*}{ No. } & \multirow[t]{2}{*}{ Phenolic compounds } & \multicolumn{3}{|c|}{ Phenolic ( $\mu \mathrm{g} / \mathrm{g}$ D.W) } & \multirow[b]{2}{*}{$\begin{array}{l}\text { Regenerated } \\
\text { shoots }\end{array}$} \\
\hline & & $\mathrm{Rt}^{*}$ & Leaves & Calli & \\
\hline 1 & Gallic & 7.041 & 33.88 & 2.7 & 7.31 \\
\hline 2 & Pyrogallol & 7.243 & 8.81 & 5.95 & 9.5 \\
\hline 3 & 4-amin-benzoic & 7.842 & 14.83 & 0.9 & 3.88 \\
\hline 4 & Protocatechuic & 8.52 & 19.09 & 2.9 & 4.49 \\
\hline 5 & Catechin & 8.63 & 21.46 & 1.9 & 4.33 \\
\hline 6 & Chlorogenic & 9.071 & 47.99 & 6.2 & 9.37 \\
\hline 7 & Catechol & 9.541 & 24.07 & 7.2 & 7.85 \\
\hline 8 & Epicatechin & 9.661 & 15.84 & 4.1 & 7.1 \\
\hline 9 & Caffeine & 9.743 & 22.68 & 1.1 & 1.7 \\
\hline 10 & P-hydroxybenzoic & 9.988 & 49.48 & 15.5 & 16.55 \\
\hline 11 & Caffeic & 10.297 & 0 & 1.4 & 3.4 \\
\hline 12 & Vanillic & 10.386 & 19.67 & 1.7 & 1.99 \\
\hline 13 & P-coumaric & 11.716 & 28.66 & 15.3 & 17.55 \\
\hline 14 & Ferulic & 11.928 & 13.2 & 4.6 & 10.35 \\
\hline 15 & Iso-ferulic & 12.322 & 0 & 4.2 & 6.42 \\
\hline 16 & Resveratrol & 12.813 & 13.8 & 0.5 & 1.73 \\
\hline 17 & Ellagic & 13.076 & 12.09 & 11.7 & 1.03 \\
\hline 18 & E-vanillic & 13.187 & 20.29 & 0 & 11.55 \\
\hline 19 & a-coumaric & 13.533 & 17.55 & 0.9 & 1.54 \\
\hline 20 & Benzoic & 13.729 & 40.52 & 18.2 & 21.75 \\
\hline 21 & 3,4,5-methoxy-cinnamic & 14.14 & 28.56 & 1.4 & 1.71 \\
\hline 22 & Coumarin & 14.307 & 54.1 & 0.5 & 3.73 \\
\hline 23 & Salicylic & 14.628 & 22.92 & 29.6 & 23.1 \\
\hline 24 & Cinnamic & 15.542 & 91 & 1.3 & 5.62 \\
\hline 25 & Scopoletin & 16.192 & 57.08 & 25.30 & 26.42 \\
\hline
\end{tabular}

$1 \mathrm{IAA}+500 \mathrm{mg} / \mathrm{l} \mathrm{PVP}+0.1 \mathrm{mg} / \mathrm{l}$ thiamine HCL was the best for calli induction from internode explants. This obtained result is in contrast with Gondo et al., 1999 who induced calli from axillary buds of Persimmon (Diospyros kaki Thunb.) on half MS medium supplemented with 1 $\mathrm{mg} / \mathrm{l} \mathrm{IAA}+0.1 \mathrm{mg} / \mathrm{l} \mathrm{BA}$.

However, the best recorded regenerated media was $1 / 2 \mathrm{MS}+$ $1 \mathrm{mg} / \mathrm{l} \mathrm{Zt}+2 \mathrm{mg} / \mathrm{l} \mathrm{IAA}+4 \mathrm{mg} / \mathrm{l} \mathrm{BA}+500 \mathrm{mg} / \mathrm{l} \mathrm{PVP}$. This obtained results are in agreement with Wang et al., 2010 who used MS medium for shoots regeneration from shoot tip of Boaibayuehuang Diospyros kaki.

Regarding identification of extracted and isolated phenolic compounds from leaves of intact plant or calli and regenerated shoots of Diospyros kaki L. cv. Costata growing in Egypt; the RP-HPLC technique
Table 5 Results of phenolic compounds identified by RP-HPLC in different extracts ( $80 \% \mathrm{MeOH})$ of leaves, calli, and regenerated shoots of Diospyros kaki L. CV. Costata that appeared at $\lambda_{\max } 330 \mathrm{~nm}$

\begin{tabular}{|c|c|c|c|c|c|}
\hline \multirow[t]{2}{*}{ No. } & \multirow[t]{2}{*}{ Phenolic compounds } & \multicolumn{4}{|c|}{ Phenolic ( $\mu \mathrm{g} / \mathrm{g}$ D.W) } \\
\hline & & $\mathrm{Rt}^{\mathrm{a}}{ }^{\mathrm{a}}$ & Leaves & Calli & $\begin{array}{l}\text { Regenerated } \\
\text { shoots }\end{array}$ \\
\hline 1 & Luteo.6-arbinose 8-glucose & 9.352 & 7.83 & 65.1 & 70.4 \\
\hline 2 & Luteo.6-glucose 8-arbinose & 10.551 & 39.28 & 4.6 & 8.57 \\
\hline 3 & Apig. 6-arbinose 8-glactose & 11.563 & 31.86 & 5.4 & 10.09 \\
\hline 4 & Apig. 6-rhamnose 8-glucose & 11.909 & 57.8 & 7.6 & 14.99 \\
\hline 5 & Apig. 6-glucose 8-rhamnose & 12.071 & 19.33 & 12.9 & 14.83 \\
\hline 6 & Luteolin & 12.193 & 62.59 & 0 & 0 \\
\hline 7 & Luteol. 7-glucose & 12.322 & 9.42 & 2.3 & 0 \\
\hline 8 & Narengin & 12.4 & 50.18 & 12.8 & 16.26 \\
\hline 9 & Rutin & 12.467 & 41.98 & 4.6 & 7.94 \\
\hline 10 & Quercetin-3-O-glucoside & 12.506 & 0 & 1.5 & 0 \\
\hline 11 & Hisperidin & 12.636 & 33.26 & 5.8 & 0 \\
\hline 12 & Kam.3,7-dirhamoside & 12.907 & 0 & 0 & 3.68 \\
\hline 13 & Rosmarinic & 12.923 & 38.29 & 1.1 & 5.66 \\
\hline 14 & Apig.7-O-neohespiroside & 13.063 & 6.86 & 2.1 & 7.51 \\
\hline 1154 & Apig.7-O-glucose & 13.257 & 13.93 & 1.5 & 7.54 \\
\hline 16 & Quercetrin & 13.409 & 23.84 & 0.9 & 1.89 \\
\hline 17 & Narengenin & 14.954 & 0 & 0 & 5.04 \\
\hline 18 & Quercetin & 14.979 & 10.21 & 1.1 & 4.86 \\
\hline 19 & $\begin{array}{l}\text { Kamp.3,(2-p-coumaroyl) } \\
\text { glucose }\end{array}$ & 15.129 & 21.96 & 0 & 0 \\
\hline 20 & Hespertin & 15.616 & 42.38 & 4.7 & 0 \\
\hline 21 & Kaempferol & 16.38 & 80.9 & 0.7 & 5.48 \\
\hline 22 & Rhamnetin & 16.551 & 15.9 & 0.7 & 2.23 \\
\hline 23 & Apigenin & 16.715 & 11.09 & 1.6 & 2.01 \\
\hline 24 & Acacetin & 18.874 & 12.30 & 3.48 & 3.81 \\
\hline
\end{tabular}

${ }^{\mathrm{a}} \mathrm{Rt} .($ retention time)

was performed. The extracted results indicated that methanolic extract showed rutin, gallic acid, caffeic acid, chlorogenic acid, kaempferol, and quercetin. The obtained results were in agreement with Quezon and Ysrael (Quezon \& Ysrael, 2014) who indicated that rutin was isolated from ethanolic extract of Disopyros pilosanthera intact plant. Moreover and in close with our obtained results Cho et al., (Cho et al., 2015) identified gallic acid, caffeic acid, myricitrin, chlorogenic acid, kaempferol, and quercetin in methanolic extract of Diospyros Lotus.

\section{Conclusions}

From the obtained results of biotechnological and HPLC analysis on Egyptian Diospyros kaki L. cv. Costata, it indicates a promising protocol for sterilization, development, 
calli induction, and shootlet regeneration of Egyptian Diospyros kaki L. In addition to qualitative and quantitative estimation of secondary metabolites.

\section{Abbreviations}

$\mathrm{Hg}_{2} \mathrm{Cl}_{2}$ : Mercuric chloride; WPM: Woody plant medium; Zt: Zeatin: 2iP: Isopentenyl adenine; MS: Murashige and Skoog medium; IAA: Indole-3acetic acid; PVP: Polyvinylpyrrolidone; BAp: Benzylaminopurine; RPHPLC: High-performance liquid chromatography; $\mathrm{KOH}$ : Potassium hydroxide; $\mathrm{HCl}$ : Hydrochloric acid

\section{Acknowledgements}

This work was MS.c student thesis and supported by National Research Centre who provided the necessary support to carry out this work, Cairo, Egypt.

\section{Authors' contributions}

Seham S. El Hawary: Supervised the experimental work and reviewed the manuscript. Soad Hanna Tadros: Supervised the experimental work and reviewed the manuscript. Hussein Taha: Designed the experimental work, participated in analysis and interpretation of the data, and reviewed the manuscript. Mona Abdelmohsen: Participated in analysis and interpretation of the data and reviewed the manuscript. Naglaa Mohamed Nazif: Supervised the experimental work and reviewed the manuscript. Iman El Sheikh: Carried out the experimental work of the manuscript, participated in analysis and interpretation of the data, and was a major contributor in writing the manuscript. Medhat Seif El- Nasr: Supervised the experimental work and reviewed the manuscript. The author(s) read and approved the final manuscript.

\section{Funding}

The study was funded by National Research Centre, Cairo, Egypt.

\section{Availability of data and materials}

The datasets used and analyzed during the current study are available from the corresponding author on reasonable request.

Ethics approval and consent to participate Not applicable.

\section{Consent for publication}

Not applicable.

\section{Competing interests}

The authors declare that they have no competing interests.

\section{Author details}

'Pharmacognosy Department, Faculty of Pharmacy, Cairo University, Cairo, Egypt. ${ }^{2}$ Biotechnology Department, National Research Centre, 33 El Bohouth St. (Former El Tahrir St.), Dokki, P. O. 12622, Giza, Egypt. ${ }^{3}$ Phytochemistry Department, National Research Centre, 33 El Bohouth St. (Former El Tahrir St.), Dokki, P. O. 12622, Giza, Egypt.

Received: 21 October 2019 Accepted: 14 April 2020

Published online: 24 May 2020

\section{References}

Cho B, Yin H, Fang C, Kim S, Jeong S, Jang S (2015) Hepatoprotective effect of Diospyros lotus leaf extract against acetaminophen-induced acute liver injury in mice. Food Sci Biotechnol 24(6):2205-2212

De Vera EP, Santiago LA (2014) Toxicity profiling and assessment of in vitro antimicrobial activity of Diospyros Philippinesis a.D.C. (Ebencace) methanolic leaf extract. World J Pharm Res 3(4):126-149

Fathi M, Mohamed A and Abd El-Bary A. Effect of Sitofex (CPPU ) and GA3 Spray on fruit set, fruit quality, yield and monetary value of "Costata" Persimmon. Nature and Science. 2011, 9(8)

Giordani E, Nava M. and Benelli C. Protocols for micropropagation of selected economically-important horticultural plants, Methods in Molecular Biology. Springer Science+Business Media New York. 2013, 11013, DOI https://doi.org/ 10.1007/978-1-62703-074-8_7.
Gondo M, Tanaka N, Tanaka T, Shimomura K, Nakanishi F, Ishimaru K (1999) A naphthalene gylcoside from callus cultures of Diospyros kaki. Phytochemistry 51:879-881

Goupy P, Hugues M, Boivin P, Amiot MJ (1999) Antioxidant composition and activity of barley (Hordeum vulgare) and malt extracts and of isolated phenolic compounds. J Sci Food Agric 79:1625-1634

Jha S, Sahu NP, Mahato SB (1988) Production of the alkaloids emetine and Cephaeline in callus cultures of Cephaelis ipecacuanha. Planta Med 54:504-506

Matsushita Y, Jang I, Imai T, Fukushima K, Lee S (2010) Naphthalene derivatives from Diospyros kaki. The Japan Wood Research Society 56:418-421

Mattila P, Astola J, Kumpulainen J (2000) Determination of flavonoids in plant material by HPLC with diode-Array and electro-Array detections. J Agric Food Chem 48:5834-5841

Monaco LC, Lopes CR, Carelli ML (1977) Isomeros deacido chloregenico em species de coffea, Ciencia. Recife 26:240

Motaleb M A, Hossain M K, Sobhan I, Alam M K, Khan N A and Firoz R. Selected Medicinal Plants of Chittagong Hill Tracts. International union for conservation of nature. Dhaka, Bangladesh. 2011.

Nigra HM, Caso OH, Guilietti AM (1987) Production of solanum by calli from different parts of Solanum eleaginifolium Cav, plants. Plant Cell Rep 6:135-137

Phillipson J D. Plants as source of valuable products: In. Secondary products from plant tissue culture. (eds) Charwood, B.V. and Rhodes, M.J.C, 1-23.Press in Oxford, New York, Toronto. 2005.

Quezon M, Ysrael M (2014) Antioxidant and hepatoprotective activities of the ethanolic extract of the leaves of Diospyros pilosantherablanco (family Ebenaceae) in diethel nitrosomine-indused rat liver toxicity. World J Pharm Res 3(8):842-862

Ramachandra RS, Ravishankar GA (2002) Plant cell cultures: chemical factories of secondary metabolites. Biotechnol Adv 20:101-153

Shirley B W. Falavonoid biosynthesis a control model for genetics,biochemistry, cell biology, and biotechnology. Plant Physiol 2000, 42: 485- 493.

Snedecor GM, Cohchran WG (1967) Statistical methods 5 th Ed. lowa State Collage, Press, Amcr lowa, U.S.A

Taha HS, Abd El-Rahman RA, Maharik NT (2009) In vitro production of caffic acid derivatives in calli and regenerate cultures of Echinacea Angustifolia dc and Echinacea Pallida Nutt. J App Sci Res 5(1):13-20

Tang W, Eisenbrand G (1992) Chinese drugs of plant origin. Springer-Verkag:931-943

Toppei G, Witte L, Riebesehi B, Von Borstel K, Hartman T (1987) Alkaloid patterns and biosynthetic capacity of root cultures from some pyrrolizidine alkaloid producing Senecio spp. Plant Cell Rep 6:466-469

Wang S, Tong R, Zhai B, Li L (2010) Effect factors on tissue culture of Boaibayuehuang Diospyros kaki. Hunan Agric Univ 36(2):176-180

\section{Publisher's Note}

Springer Nature remains neutral with regard to jurisdictional claims in published maps and institutional affiliations.

\section{Submit your manuscript to a SpringerOpen ${ }^{\circ}$ journal and benefit from:}

- Convenient online submission

- Rigorous peer review

- Open access: articles freely available online

High visibility within the field

- Retaining the copyright to your article

Submit your next manuscript at $\boldsymbol{\nabla}$ springeropen.com 